Against Extinction: The Story of Conservation by William M. Adams (2004), xvi + 311 pp., Earthscan, London, UK. ISBN 1844070557 (hbk), £55.00, ISBN 1844070565 (pbk), £16.95.

Against Extinction: The Story of Conservation uses the opportunity of the 100th anniversary of Fauna \& Flora International, the world's oldest conservation organization, to go back to the roots of the movement and assess its achievements. Bill Adams is articulate and conscientious in his detailing of the shifts in policy over the decades, bringing to life many of the characters and organizations that have contributed to the great cause of maintaining the diversity of life on Earth. Enlightened self-interest rather than altruism lies behind each new phase but, even so, humankind's apparent inability to take a longer view is a thread that, depressingly, will challenge optimists everywhere.

Adams' treatise is authoritative, comprehensive and objective; he handles the subject matter formally and systematically. With 240 pages of closely typed text, more than 1,200 references, no maps or graphs and few pictures for light relief, the reader is challenged tempted to take short cuts, skip parts and move on - but I found myself continuously hauled back to check the story, required by the author to make sense of it all.

The book makes no bones about focusing on European initiatives, particularly in Africa. It begins with the role of zoos and museums in sensitizing western Europeans to the wonders of nature; the hunters deployed around the world to collect specimens were perhaps the first to recognize the vulnerability of rare species such as the mountain gorilla, discovered as recently as 1902 . Those were heady days when everything and everyone knew their place and the ruling classes carried noblesse oblige to the jungles of the European empires. Ethical and moral principles, thinly disguising imperial colonialism and a lust for adventure, saw parks created and species protected as a resource for hunting and recreation. One hundred years later, more than $11 \%$ of the Earth's land surface is protected in parks. International regulations prevent unsustainable trade, protect migratory species, identify and conserve world heritage areas and parade 'biodiversity' as a vital resource for all people. The reader is left in no doubt that without the efforts of the conservation movement the world would be in a far sorrier state than it is. So much has been achieved - but is it enough?
After the Second World War the moral arguments for conservation, however genuine or passionately held, were swept away by the advancing juggernaut of global population and economic growth. The seductive idea of sustainable use took centre stage, an expedient way to conserve your species and eat it, so to speak. Adams hunts for examples of sustainable use in practice but, like others before him, cannot make a convincing case. The sorry stories of whales, of elephants, and particularly of fisheries, are stark evidence of humanity's demonstrable inability to regulate voluntarily or by rule of law. Despite the amazing growth of the conservation movement and its work, the problems have grown faster still. With one species gulping down more than $40 \%$ of the Earth's productivity it comes as no surprise that there is less to go around for the other 12 million or so, and extinction is 100 to 1,000 times faster than the background rate. The reader is left flinching at the crass stupidity and lack of political will that have caused destruction of theoretically renewable biological resources on a massive scale. Humanity is apparently helpless, hapless, even hopeless, when faced with the need to be sensible and manage resources effectively.

By the end of the 20th century the story of conservation has become highly complex, multi-faceted and political. Conservation is no longer about nature but about people and nature, or perhaps more properly people in nature. Conservation is an integral part of debates about poverty, human rights, development and sustainability. Developing nations around the world are demanding compensation for their stewardship of the world's species, and a fair share of the revenues arising from their use in providing our food, fibre and pharmaceuticals. Adams' account is mainly the story of Western conservation - a set of objectives, principles and methods that have prevented the worst from happening but are no longer stemming the tide. He brings the reader slowly, painfully and incontrovertibly to the edge of an abyss.

No punches are pulled from here on. Adams is very clear that the old ways of conservation will not serve for the future. 'Neither the creation of a national park on paper nor the decision to make trade in certain species illegal were in themselves enough to ensure the conservation of anything', he writes. After 10 decades of effort, a whole century of achievement, Adams tells us the threats to nature are not reduced but redoubled. 'The 
20th century saw conservation's creation, but nature's decline.'

He describes how conservation NGOs have responded by moving to a 'corporate model', a strategic business approach with defined and measurable goals and objectives. By identifying sectoral and geographical priorities they have attracted support from corporations and successful entrepreneurs. New injections of resources have allowed a reassessment of conservation at the community level and the potential for another crack at sustainable use. There have been many advantages: in particular, protected areas have been reassessed to see how they may be managed in cooperation with local communities. Adams welcomes the focused approach and political influence that comes from larger budgets in conservation, but between the lines one detects a reminder of the dangers of Faustian alliances and a warning that a corporate approach will always leave conservationists running after the bus. He warns against elitism and Western arrogance. 'Concepts like 'biodiversity' shut out other ideas about nature just as effectively as rooms full of Western-salaried conservation scientists mapping hotspots shut out other people.'

Adams also gives time to authors who have declared that the only solution is high fences and well-armed rangers. I sensed his sympathy with them, but in the end he rejects their arguments on the basis that the demands of the world economy mean that in $99 \%$ of cases it is the economic values of biological diversity that will determine survival. He puts perhaps undeserved faith in discerning consumers who, given the right information, will select sustainably produced commodities, and in local people who, given the right incentives, will meet market demands by caring for biodiversity. He looks at examples such as ecotourism, which can be important in places such as East Africa. But, true to the show-all-sides style, he pops the balloon by saying that ecotourism has little future in West Africa and 'forest environments, dark, wet and itchy, are only attractive to a few hardy types, and wildlife is hard to see.' He can't convince himself (or the reader) that a resource-based view is much better than a protectionist one.

Against Extinction is more of an interpretative history than a political critique, but in the closing chapter the author shows his real colours. He gives a palpable sigh of relief that he has compared and contrasted, summarized and filed all the formal papers, and can now turn to the real issues. In his tenth and final chapter Adams casts aside the mantle of historian, geographer and academic and adopts an assertive style of text with strongly held opinions. He challenges the reader (and himself) to make sense of it all, drawing on metaphors from chess to Harry Potter to capture the multi-dimensional complexity of conservation and its problems. He paints a grim picture of a world driven by consumer demand and fuelled by ecosystem engineers, deploying all-powerful technologies to harvest, transform and simplify the Earth at will. It is not only species that are being lost: languages, cultures, traditions and informal knowledge are all falling before the grim reaper. Ironically, he finds that the problems we face today are similar to those of a century ago, but much more intense. Worryingly, the solutions we are trying are much the same as well, but none of them promises the scale shift needed to halt extinctions. Nature will become increasingly isolated from humanity, confined to the modern protected area; little more than a whizz-bang equivalent of the zoo or museum of a century ago.

In his closing paragraphs Adams calls for new thinking about what nature is, why we need it and how we could restore it. Recognizing that in our postmodernist era people take decisions based primarily on individual ambitions, he says that conservation urgently needs to make sense to ordinary people. The conservation construct (for that is what it is, and not an empirically derived mandate) should be based on a fusion of local and external, traditional and scientific knowledge. Vitally, this knowledge should be used within decisionmaking processes that include the widest possible participation of stakeholders. Conservation has become more of a social and political science than a natural one.

Adams implies that conservationists today are like gardeners, working with the tools they have, blunt and bent, within flimsy fences that they have erected to hide the nastiness outside. Against Extinction challenges conservationists to sweep aside its fences and tools, its institutions and philosophies, to think anew and build a fresh, joined-up paradigm for the future. The author reminds us that conservation is about choices we make about our engagement with other species. But the stakes have been raised and it is the very resilience of ecosystems that is now in question - resilience that derives from the diversity of nature and its ability to heal itself. With $50 \%$ of humanity confined to great cities it is no wonder that we have lost touch with the meaning and value of nature. Conservation for the next 100 years has to be about reconnecting with nature in a way that has meaning for the common man.

Mark Collins

United Nations Environment Programme

P.O. Box 30552, Nairobi, Kenya

Of Partridges \& Peacocks - and of Things About Which I Knew Nothing by D. Jenkins (2003), TLA Publishers, Aboyne, UK. ISBN 0954627709 (pbk), £21.00.

Autobiographies are all the more engaging when they explain things that have been puzzling the reader for 
decades. In this case it is the author's allegiances - always difficult for a younger colleague (me) to fathom. All is now clear - they were all at University together, and Jenkins gained a degree from each point of the 'golden triangle', London, Cambridge and Oxford, and had plenty of opportunity for making friends. His autobiography is a fascinating account of his life as ornithologist, research manager and international conservationist. Trained initially as a vet, he was easily bored, but fired with enthusiasm for ornithology as a result of student expeditions from Cambridge, he turned to the challenge of research. He joined the Oxford Bureau of Animal Populations for a PhD study of grey partridges on J. Arthur Rank's Hampshire estate. He then became the first member of the grouse unit established in north-east Scotland by the Scottish Land Owners Federation and the Nature Conservancy, and where work on Galliformes has continued unbroken for nearly 50 years. Next came Assistant Directorship of Research for the Scottish Nature Conservancy, based in Edinburgh, and after the break up of the Nature Conservancy into The Nature Conservancy Council and the Institute of Terrestrial Ecology (ITE), Jenkins became head of ITE's Banchory Research Station, part of the Natural Environment Research Council (NERC). NERC had difficulty in deciding how best to manage its science and Jenkins was soon given responsibility for vertebrate ecology across all its research stations, from Aberdeen to Dorset. He enjoyed this, but then NERC reverted to management by location rather than by discipline and Jenkins reverted to being head of station. Seventeen years after he retired, NERC have returned to managing by discipline! Throughout his book, Jenkins extols the strengths, cost effectiveness and scientific value of small teams working under competent management. This is certainly an autobiography for today's science managers!

In 1977 The World Pheasant Association (WPA) recruited Jenkins as a scientific advisor, and this led to his extensive involvement in international conservation, in Pakistan (where the release programme for the Cheer Pheasant makes particularly interesting reading) and in Indonesia. Although this is the section of the book self-deprecatingly referred to in the subtitle as 'things about which I knew nothing', Jenkins brought a wealth of experience to WPA and tried hard to encourage younger scientists in the countries that he visited to achieve higher qualifications. He also helped WPA to organize scientific meetings.

A strand running through the book was his good relationship with landowners and the importance he gave to involving stakeholders, long before that word was invented! He frequently brought together scientists, landowners and their gamekeeper to share ideas about land and water management. Landowners sought his advice too, and he recounts advising Lord Iveagh on the management of his Breckland estate.

Jenkins writes clearly and frankly. A major part of his career was his role as a critic and editor of colleagues' papers, but there is little sign of his talents in that respect in his autobiography. It is overlong, often giving the impression of being transcribed directly from his journals and diaries. It would have benefited from some distillation, although that detracts little from the pleasure of reading it, which made Jenkins, often a rather choleric character to younger colleagues, more endearing.

Paul A. Racey

School of Biological Sciences, University of Aberdeen

Aberdeen, AB24 2TZ, UK

E-mail p.racey@abdn.ac.uk

Amur Tiger by David Prynn (2004), x + 214 pp., Russian Nature Press, Edinburgh, UK. ISBN 0953299031 (pbk), $£ 15.00$.

The Russian Nature Press, a not-for-profit company that promotes conservation in the former Soviet Union, brings us another one of their fine publications, this time on the Amur Tiger. The book is handsomely illustrated with black and white drawings, and made all the more interesting by the inclusion of seven stories, of 15 chapters, translated from their original Russian by G.H. Harper. Amur Tiger is packed with information about the historical, social, geographical, climatic, botanical, and ecological setting that brings us from the not too distant past to the conservation crisis in which we find the Amur tiger and Amur leopard today. Both the nature lover and natural history buff will find the book worthwhile.

We are told in the Author's Note that the Amur tiger, $A m b a$, is the 'great sovereign or master of the forests' to the native people and that the tiger is an 'important cultural icon and magnificent symbol of the heritage of the indigenous people, Russians, Chinese and Koreans, giving special significance to the region.' This exalted status, however significant, has not been enough to protect the tiger, its prey, and its habitat from relentless exploitation. The same can probably be said of other extinct subspecies of tigers, such as the Caspian tiger.

Many readers will already be somewhat familiar with the Amur tiger and its current dilemma. Amur Tiger is a must read for several reasons. The book brings together disparate information on the history of the region and its people, and describes in fascinating detail the biogeographical context of the region. I read with fascination the description of the oak forests, for instance.

The translated stories were also of special interest, although, as one might expect each human-tiger interaction rarely ends in a favourable outcome for the tiger. The 
lucky ones limp away forever maimed. Despite their special importance, tigers are trapped for zoos, shot for sport or protection, and trapped for their skin and bones. Their prey, especially wild pigs, are consumed by humans, and tigers must compete with Amur leopards for food, and their habitat is continually encroached upon or cleared and shipped away. All humans know that dead trees are worth more than live ones, and the Russian Far East is no exception. Some will find the killing of tigers objectionable. They need only skip the even numbered, translated chapters. We learn that today tigers are now subsisting on scant wild prey and domestic dogs, one of the few subsidies humans have unintentionally provided them.

Thus, Amur Tiger is a timely book about a vanishing subspecies and indeed other equally rare and beautiful subspecies such as the Amur leopard, and the monumental efforts conservationists are making to save these species from extinction. While the author 'has studied Amur tigers', in reality he comes and goes as a visitor. The groundwork on conservation is being undertaken by resident biologists, both native and foreign, who have for many years dedicated their professional endeavours to addressing the conservation crisis in the Russian Far East. Moreover, by the length of the list provided in Appendix 3 of NGOs and other organizations working in the region there is doubtless no end to the political crises that these conservationists must endure.

Although the Publisher's Note states that the chapters can be read in any order, I would not recommend this approach. Why would we read about the future without first understanding the past? The even numbered chapters (the translated stories of the past) can, however, be read without reading any other chapters and indeed specialists might find these stories entertaining and interesting in their own right. There were a few typographical errors that should have been caught during editing. 'We swopped ideas' in the tiger monitoring chapter was my favourite. Also, I found the repeated use of terms like 'different kinds of tigers' and 'main kinds of tigers' to be a bit annoying. Why not explain the scientific term 'subspecies' and use it throughout? Surely readers of Amur Tiger understand that the island tigers of Bali, Java, and Sumatra, for instance, are all subspecies of tigers.

Additionally, I found most frustrating several cryptic references to something called the 'small forest cat'. This small cat was not given in the list of mammals in Appendix 1 , though it is indeed a mammal, and it has no Latin name in the text. Most readers will not give this treatment a second thought. However, being a small cat specialist for the IUCN Cat Specialist Group I cannot let this omission pass so lightly. This cat, no bigger than a house cat, can only be the very interesting Amur leopard cat (presently Prionailurus bengalensis and lumped with the common Leopard cat of Asia) that the Russians still maintain to be a separate and distinct species of cat.

In the end anyone that reads this little gem already hopes that the Amur tiger can be saved from extinction. However, hope will clearly not be enough to ensure the Amur tiger survives.

Jim Sanderson

Center for Applied Biodiversity Science, Conservation International Washington, DC 20026, USA

E-mail gato_andino@yahoo.com

The Return of the Unicorns: The Natural History and Conservation of the Greater One-Horned Rhinoceros by Eric Dinerstein (2003), xviii + 316 pp., Columbia University Press, New York, USA. ISBN 0231084501 (hbk), £36.00.

Saving the species of Rhinoceros is one of the most difficult conservation challenges faced by us today. Ironically, rhinos were remarkably successful and widespread animals throughout their 40 million year evolutionary history. Rhinos that survive now (three species in Asia and two in Africa) all number in only dozens or hundreds at best, due to relentless poaching and habitat encroachment.

Beginning in 1984 Eric Dinerstein, who now leads conservation science at WWF-US, undertook the definitive ecological study of the Asian greater one-horned rhinoceros. Starting as a single research project, Dinerstein's work then blossomed into a long-term investigation of the flood-plain ecosystem and, ultimately into a pioneering conservation initiative. His account of this journey is breathtaking in its scope: it spans the evolution of Rhinoceros, brief accounts of all surviving species, and is a major tour de force on the ecology of the greater one-horned rhino. Dinerstein also skilfully manages to weave into his tale fascinating strands of ecological theory and personal anecdotes. If he had just stopped at this point, the book would still have been a solid reference volume of great value to students of wildlife ecology. But fortunately he does not. Driven not just by scientific curiosity, but also by his childhood passion for wildlife, Dinerstein goes on to blend into this tale the history of the efforts to save the mighty beast - the Gaida of the Himalayan Terai. His conservation history rests not just on solid ecology but also on deep personal insights into the sociology of practising conservation in Asia.

A fascinating aspect of The Return of the Unicorns is the manner in which Dinerstein critically analyses contentious issues in ecological theory and conservation practice: evolution of life-history traits in mammals, importance of genetic versus demographic factors in 
species recovery, and the merits and demerits of 'ecotourism' and 'eco-development'. He weaves all these complex issues into 12 chapters of text backed up by several data-rich appendices. The book is profusely illustrated with informative photographs, diagrams, graphs and maps.

The author has tried to follow George Schaller's advice to conservation scientists: 'Natural history provides the basis for understanding the requirements of a species, something that researchers often disregard in this age of remote-sensing and computer modelling. Yet describing an animal is not enough: a researcher today also has a moral responsibility to help the species endure.' Dinerstein has succeeded admirably in his mission, this book is essential reading for all ecologists and conservationists.

K. Ullas Karanth

Wildife Conservation Society - India Program, 26-2 Aga Abbas Ali Road (Apt: 403), Bangalore, Karnataka-560 042, India

E-mail ukaranth@vsnl.com

Biodiversity: An Introduction (Second Edition) by Kevin J. Gaston \& John I. Spicer (2004), xv + 191 pp., Blackwell Publishing, Oxford, UK. ISBN 1405118571 (pbk), £19.99.

This book has been revised and updated only 6 years after the first (1998) edition due to (1) rapid progress in understanding many key issues, (2) large increases in the literature on biodiversity, (3) changes in university course structure from a taxonomic to a biodiversity approach, and (4) little/no reduction in the level of threat to the variety of life on Earth. The book is divided into six chapters. Each has a small summary and a useful, annotated list of references (mostly books) for further reading. The articles cited in each chapter are all listed together at the end of the book. All chapters are illustrated with clear, straightforward, black-and-white diagrams and graphics. There is also an index.

Chapter 1 (What is biodiversity?) covers ecological, genetic and organismal views of biodiversity, the strengths and weaknesses of different species concepts, and the use of species richness to measure biodiversity. It is the only chapter to give some internet sources. Chapter 2 (Biodiversity through time) uses information from the fossil record and from molecular data to provide a brief history of biodiversity, covering diversification and extinction. A section of this chapter tries to answer the question 'How many extant species are there?' Chapter 3 (Mapping biodiversity) is the longest chapter and gives an excellent overview of the many different ways of viewing and measuring biodiversity. Using species-area and local-regional richness relationships, the authors explore biodiversity using the biological realm, biogeographic region, hotspot and endemism perspectives, noting that we still know relatively little about the biodiversity of tropical forest canopies, soils, coral reefs and the deep ocean. How biodiversity varies across latitudinal, elevational and depth gradients and across peninsulas and bays is also covered. The chapter ends with consideration of congruence, or rather its lack, between species richness of different taxonomic groups. The chapter contains many diagrams that clearly illustrate the concepts and relationships. Chapter 4 (Does biodiversity matter?) covers direct use values (food, medicine, biological control, industrial materials, recreational harvesting, ecotourism) and indirect use values (ecosystem functioning) as well as non-use values (option, bequest, existence and intrinsic values) of biodiversity. This chapter on values is followed by one exploring human impact. The impact is, of course, negative. The chapter focuses on species loss, exploring the level of loss and then the four principal proximate causes: overexploitation (for example of bushmeat, fuelwood, marine fisheries), habitat loss and degradation (including climate change), introduced species and extinction cascades. The ultimate causes of human impact human population size, population growth, scale of human enterprise - are also explored. This chapter lastly sets out human impact on primary production (we use about $40 \%$ of it from terrestrial sources), energy use and water use $(>25 \%$ of terrestrial evapotranspiration, $>50 \%$ runoff) from growing per capita consumption. The final chapter (Maintaining biodiversity) focuses on the Convention on Biological Diversity, in particular on Articles 6 (general measures for conservation and sustainable use), 7 (identification and monitoring), 8 (in situ conservation), 9 (ex situ conservation), 10 (sustainable use of components of biological diversity) and 11 (incentive measures). The authors conclude that until significant progress is made in establishing specific targets and reporting protocols (to judge progress), biodiversity will continue to decline as a consequence of human activities.

The authors state that their goals for both editions of this book are the same: to provide a text giving an introduction to biodiversity and to present an entry point into the wider literature on biodiversity. They have more than met their goals and this book will be useful not just for university students but also for people working in conservation and advocacy organizations, in zoos and aquaria, and the media.

Anna T.C Feistner

AFP Conservation Support, Tunbridge Wells, Kent, TN2 4TL, UK

E-mail anna@feistner.com 
Ecological Genetics: Design, Analysis, and Application by Andrew Lowe, Stephen Harris \& Paul Ashton (2004), xi + 326 pp., Blackwell Publishing, Oxford, UK. ISBN 1405100338 (pbk), £29.99.

It has often been said in recent decades that evolutionary biology, and in particular the sub-disciplines within this field that rely on DNA-based methodologies, is in the midst of a technical revolution. Thanks in part to the various genome projects, automated sequencing and genotyping, and high-throughput spin-offs of medical and agricultural genetic programmes, molecular ecology and conservation genetics have benefited greatly. With the publication of Ecological Genetics the ever-widening horizon of molecular applications to ecological science has gained an updated, cohesive and valuable resource.

The book begins with an introductory chapter that summarizes the history of the field, lending context to the state of the field today in the post-synthesis, DNAdominated world of ecological genetics. In Chapter 2 an emphasis on sampling strategy and issues of experimental design will be especially helpful to graduate students and researchers facing some of the initial challenges of project planning. Methodologies are outlined, including good summaries of widely used molecular markers in Essential Methods Information, along with their basis, applications, advantages and disadvantages. Chapter 3 looks at the factors affecting genetic diversity and how genetic differentiation is quantified and compared. Some of the common tests used are described, and their strengths and weaknesses are illustrated with case studies. Chapter 4 examines the importance of reproductive strategy, reproductive barriers, and dispersal ability in the context of evolutionary history and gene flow. The focus of Chapter 5 is on phylogeography, and intraspecific evolutionary processes are examined in a biogeographical context. Various methods are described and again case studies are used to highlight the approaches outlined. Chapter 6 looks at species concepts and tackles some basic speciation theory, ways in which the process of speciation can be demonstrated, and covers concepts of interspecific hybridization, introgression and hybrid zones. Finally, Chapter 7 presents four case studies using butterflies, ragworts, bears and oak trees as examples, showing how the concepts presented in the book can be applied. There are two appendices, Appendix A listing nearly 50 analytical software packages, their basic features and where to get them, and Appendix B covering genetic distance algorithms, and finally, a glossary.

A recurrent theme that is developed and interwoven throughout the book is the integration of field and laboratory investigations, from experimental design to identification of a clear testable hypothesis and interpretation of the derived biological data. Also useful, and of particular interest to students, will be the feature of the first page of each chapter offering a synopsis of what is to follow. I enjoyed the book, including the use of relevant historical quotations, interesting and helpful use of empirical examples throughout, as well as the brief, though up-to-date coverage of markers, techniques and analytical software. Examples in the text are given of studies using tools that many students find conceptually difficult, including microsatellites, AFLPs, networks, fractional paternity assignment, coalescent theory, maximum likelihood estimation, and nested clade analysis. There are references throughout the book to conservation implications of molecular data and the impacts of invasive species, which I find particularly timely and appropriate in the context of the ongoing extinction crisis. The laboratory techniques covered are strongly biased towards molecular tools, reflecting again the notion that direct access to genetic material has opened up a multitude of potential questions that could not be tackled by ecologists as recently as 20 years ago. Publication of this book effectively brings the field of ecological genetics into the modern molecular age. I would strongly recommend Ecological Genetics as a text for upper-division undergraduate as well as postgraduate level courses in this discipline. In all I find it an excellent, well-written, well-referenced resource for advanced students as well as researchers striving to stay on top of the burgeoning field of molecular applications to ecological genetics.

Brenden Holland

Center for Conservation Research and Training, University of Hawaii 3050 Maile Way, 408 Gilmore Hall, Honolulu, HI 96822, USA E-mail bholland@hawaii.edu

Biodiversity of West African Forests: An Ecological Atlas of Woody Plant Species edited by L. Poorter, F. Bongers, E.Y.N. Kouamé \& W.D. Hawthorne (2004), 521 pp., CABI Publishing, Wallingord, UK. ISBN 0851997341 (hbk), £85.00.

The rainforests of West Africa, the Upper Guinean forests, are considered to be one of the world's biodiversity hot spots. They contain c. 2,800 vascular forest plant species of which 650 are endemic and c. 400 species are considered rare. Many of the endemic plants are threatened by deforestation, habitat fragmentation and overexploitation. This beautifully presented book will be a useful tool in their conservation. Ecological profiles are presented of 286 endemic and rare plant species and of 56 large timber species. A description of the species is given and information provided on distribution, habitat, regeneration, phenology, uses and further data sources. The IUCN threat category is given where this has been assigned. The distribution data provided on the species 
that have not yet been evaluated will in itself be valuable in undertaking further IUCN Red List assessments. Based on the aggregated distribution data for the selected rare and endemic species, hotspots of plant diversity in Upper Guinean forests are mapped. The source material for this book is largely drawn from herbaria material, illustrating how botanical collections can be used in conservation planning. Although certainly not a field guide, the book should serve to inspire further field research on poorly known species and, above all, practical conservation for species that are close to extinction.

\section{Sara Oldfield}

Fauna \& Flora International, Great Eastern House

Tenison Road, Cambridge, CB1 2TT, UK

E-mail sara.oldfield@fauna-flora.org

Promoting CITES-CBD Cooperation and Synergy. Proceedings of the Workshop, 20-24 April 2004, Isle of Vilm, Germany edited by Gisela Stolpe \& Wiltrud Fischer, Bundesamt für Naturschutz (BfN), Bonn, Germany [also available at http://www.bfn.de/en/09/ 090203.htm].

The Convention on International Trade in Endangered Species of Wild Fauna and Flora (CITES) and the Convention on Biological Diversity (CBD) share common goals of biodiversity conservation and sustainable use whilst having different emphases and modes of operation. Rhetoric about synergy and cooperation is commonplace in international policy debate but in practice these can be difficult to achieve. The workshop held in
Vilm this year aimed to increase understanding of CITES and CBD objectives, mechanisms and constraints, and to develop practical means for harmonization between the Convention processes. The proceedings, published both in print and online, provide concrete proposals for cross-cutting mechanisms and a wealth of background material to support the suggested ways forward.

The following publications have been received at the Editorial Office and may be of interest to readers:

State of the World 2004: Progress Towards a Sustainable Society: (Twenty-first Edition) by the Worldwatch Institute (2004), xxv + 246 pp., Earthscan/James and James, London, UK. ISBN 1844070654 (pbk), £14.99.

Soay Sheep: Dynamics and Selection in an Island Population edited by Tim Clutton-Brock \& Josephine Pemberton (2004), xi + 383 pp., Cambridge University Press, Cambridge, UK. ISBN 0521823005 (hbk), £80.00, ISBN 0521529905 (pbk), £33.00.

Parasites, People, and Places: Essays on Field Parasitology by Gerald W. Esch (2004), xiii + 235 pp., Cambridge University Press, Cambridge, UK. ISBN 0521815495 (hbk), £45.00, ISBN 0521894573 (pbk), £17.99.

Food Webs at the Landscape Level edited by Gary A. Polis, Mary E. Power and Gary R. Huxel (2004), xviii + 548 pp., The University of Chicago Press, Chicago, USA. ISBN 0226673279 (pbk), £25.50. 